\title{
FINANCIAL STATEMENTS \\ TIMELINESS AND REAL EARNINGS \\ MANAGEMENT IN THE EGYPTIAN \\ CONTEXT
}

\author{
Amr Nazieh Mahmoud Ezat \\ Assistant Professor, Accounting \\ Department, Faculty of Commerce, \\ Mansoura University
}




\title{
FINANCIAL STATEMENTS TIMELINESS AND REAL EARNINGS MANAGEMENT IN THE EGYPTIAN CONTEXT
}

Amr Nazieh Mahmoud Ezat

Assistant Professor, Accounting Department, Faculty of Commerce, Mansoura University

\begin{abstract}
:
Financial statements timeliness (FST) has not been given the suitable attention in the accounting literature of developing countries (e.g. Egypt). Similarly, the real earnings management (REM) activities have not been examined on a large scale for such countries. This study aims to fill this gap by investigating the impact of REM on FST for Egyptian listed nonfinancial companies from 2011 to 2013, that considers the current study to be one of the primary studies that addresses such impact. Three ordinary least square (OLS) regression models were conducted to test the main hypothesis of the study. The descriptive results indicate that, on average, Egyptian listed non-financial companies take 82 days to release their financial statements and perform REM activities, such as sales and production cost manipulations. Further, companies ranged from reporting financial statements as early as 72 days to as late as 100 days. Additionally, a multivariate analysis indicates that both models of REM (the abnormal values of sales and production cost manipulations) are associated significantly with FST. Companies that manage their earnings upward are more likely to accelerate the release of their financial statements and vise versa.
\end{abstract}




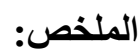

لم يلق موضوع توقيت اصدار القوائم الماليـة الإهتمـام الكافي في أدبيـات علم المحاسبة في الدول

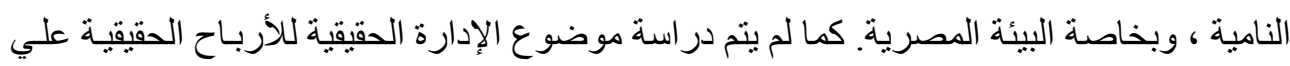
نطاق و اسع في تللك الدول. ولذلك، فإن الدراسة الحالية سوف تهنم بمعالجـة هذا النقص من خـلال فحص أثر أنشطة الادارة الحقيقية للأرباح علي توقيت اصدار القوائم المالية للثركات المصرية غير

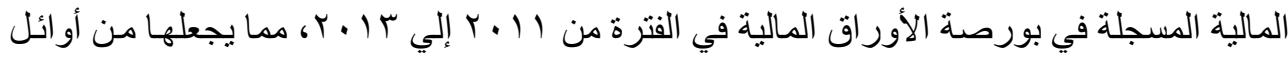
الدراسات التي قامت بفحص هذا الأثر في البيئة المصرية. ولإختبار الفرض الأساسي للار اسـة، فقد

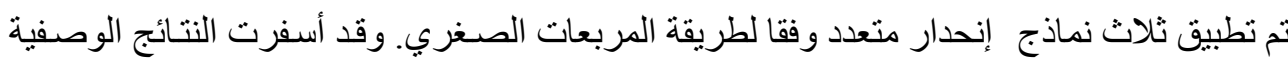
عن أن الثركات المصرية غير المالية المسجلة في البورصـة تستغرق - في المتوسط ـ ب ب يومـا لإصدار قو ائمها المالية ، كما أنها تمارس أنثطة إدارة أرباح حقيقية (منمثة في أنشطة التلاعب في لئي المبيعات وتكاليف الإنتاج). بالإضافة إلي ذلك، فإن الثركات المصرية تتراوح في إصدار ها للقو ائم المالية ما بين الإصدار المبكر( والذي يستغرق ب ل يوما) و الإصدار المتأخر (و الذي يستغرق ل. يو ما). كما أبرزت نتائج تحليل الإنحدار أن كلا من القيم غير العادية لمتغير التلاعب في المبيعات (النموذج الأول للادارة الحقيقية للارباح) ومتغير تكاليف الإنتاج (النموذج الثاني للادارة الحقيقيـة

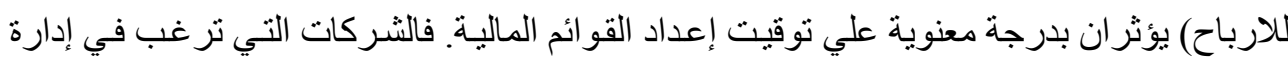

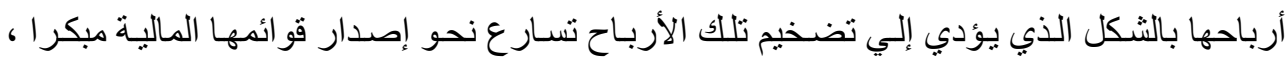

$$
\text { و العكس صحيح. }
$$

\section{Introduction}

Timeliness has long been recognized as one of the qualitative attributes of general purpose financial reports as it enhances the relevance and faithful representation of information (American Institute of Certified Public Accountants [AICPA], 1973; Accounting Principles Board [APB], 1970; FASB, 1979). Since the purpose of corporate reporting is to provide information that will aid investors in their decision making, timeliness becomes one of the most important 
characteristics of financial accounting information for the accounting profession (Soltani, 2002; Ezat and El-Masry, 2008).

Timeliness requires that information be made available to the users of financial statements as rapidly as possible (Carslaw and Kaplan, 1991). Furthermore, timeliness has become crucial due to the changes in modern technology and business practices worldwide (Afify, 2009). Owusu-Ansah and Leventis (2006) demonstrated that timely reporting enhances decision making and reduces information asymmetry in the capital market.

Additionally, Abdelsalam and Street (2007) reported that timeliness is one of the necessary components of financial information that is receiving increased attention from accounting regulators and listing authorities worldwide. Therefore, capital market professionals and regulatory bodies are concentrating on the reduction of delays in publishing financial statements (Afify, 2009). However, timeliness does not indicate that companies neglect accuracy, and companies should consider this when publishing their financial statements.

Researchers have found that stock prices are affected by the timing of earnings reports (Chambers and Penman, 1984; Kross and Schroeder, 1984; Trueman, 1990). Further, the earlier the announcement is made, the more positive the market reaction (Kross and Schroeder, 1984). Consequently, the timing of earnings reporting influences the capital market.

Prior studies demonstrate that there are many determinants for earnings reporting timeliness. For example, earnings reporting 
timeliness is related to whether the news is good or bad (Givoly and Palmon, 1982; Kross and Schroeder, 1984; Chambers and Penman, 1984; Bagnoli et al., 2002; Begley and Fischer, 1998; Cohen et al., 2007, Brown et al., 2011, Roychowdhury and Sletten, 2012; Moradi, 2013). Good news indicates that a company is performing well, which accelerates the issuance of earnings reporting. However, bad news indicates that a company is performing poorly, which decelerates the issuance of earnings reporting. Therefore, firm performance is one of the key determinates of earnings reporting timeliness.

Recently, extensive research was conducted on earnings management in developed and developing countries. Earnings management is defined as the choice of accounting policies by the manager, or the real activities that are performed to achieve certain earnings targets. Earnings management can be categorized into two methods. The first one, accrual-based earnings management, is related to changes in the accrual process. The second one, real earnings management (REM), is related to deviation from normal business activities (Enomoto et al., 2013).

In this regard, Enomoto et al. $(2013,3)$ stated that "Managers can opportunistically manage earnings by changing the accrual process because various estimations and judgments go into the process of preparing financial statements. Thus, management can implement Accrual-based earnings management after the end of fiscal year. However, accrual-based earnings management is more visible than real earnings management due to scrutiny from auditors and 
regulators, among others, and has the potential for reversal in future periods." Additionally, managers can also perform REM by changing the timing and/or structuring of the firm's various cash flow activities, specifically operating, investing, and financing.

Many aspects have been investigated in association with accrualbased earnings management. One of these aspects is the relationship between earnings announcement timeliness and accrual-based earnings management. Delaying an announcement of bad news is preferable to decrease the negative impacts of accruals manipulation (Chai and Tung, 2002). However, the association between timeliness and REM has been rarely investigated. Therefore, this study seeks to fill this gap by examining the impact of REM on FST in Egypt, which represents the main contribution of this study.

In Egypt, several legal legislations are related to the timeliness of corporate financial statements. For example, Company Law 159/1981, amended by Company Law 3/1998, states that "the board must present annual financial statements accompanied by an audit report and a report of the company's activity within three months of the fiscal year-end." Further, Capital Market Law 95/1992 and the decision of the Egyptian Financial Supervisory Authority No. 132 in 2010 stipulate that every Egyptian company must prepare financial statements according to the Egyptian Accounting Standards and the international accounting standards.

Therefore, the main objectives of this paper are to: (1) describe the current practice of FST of the Egyptian listed non financial companies 
and demonstrate whether these companies are committed to the legal period (specifically, releasing financial statements within three months of the fiscal year-end), (2) detect whether the managers of Egyptian companies perform real activities manipulation, (3) provide empirical evidence for the possible impact of REM on FST, and (4) compare the financial statements of Egyptian companies that report earnings early and late.

The remainder of this paper is organized as follows. Section 2 presents the research background for both FST and REM. Section 3 discusses previous studies related to FST. Section 4 describes the main hypothesis of this study. Section 5 details the study sample, variables measurement, and research models. Section 6 discusses the main findings. Finally, section 7 summarizes the conclusions, limitations, and opportunities for future research.

\section{Background}

\subsection{Timeliness of accounting information}

Users of financial information require accurate and timely information to make informed decisions (Modugu et al., 2012). Moreover, investors need timely information to reduce the asymmetric dissemination of financial information and grow the investment community as a whole (Jaggi and Tsui, 1999). Therefore, the usefulness of published corporate reports for stakeholders depends on their accuracy and timeliness.

According to the conceptual framework revised by IASB in 2015, timeliness "means having information available to decision-makers in 
time to be capable of influencing their decisions. Generally, the older the information is the less useful it is. However, some information may continue to be timely long after the end of a reporting period because". Therefore, having information available to decision makers before it loses its capacity to influence decisions makes the information relevant. If information is not available when it is needed, it lacks relevance and is no longer usable.

Thus, the usefulness of the information disclosed in a company's financial statements declines as the time lag increases (Hossain and Taylor, 1998). Timely reporting affects the efficiency of stock evaluation and pricing by reducing the level of insider trading, information leakage, and rumors in the stock markets and by reducing the level of information uncertainty (Che-Ahmed and Abidin, 2001).

For these reasons, companies seek to release the earnings announcements as soon as possible to preserve the timeliness of the information. If investors do not receive information at a suitable time, the information loses its value, and investors may make irrational decisions. Accordingly, Krishnan and Yang (2009) documented the trend that companies are releasing their earnings earlier than the audit report. However, this trend is not applicable in many countries, including Egypt, either because of the lack of investor awareness or because of prohibition from regulatory bodies.

As timeliness is one of the characteristics related to the quality of accounting information, Enofe et al. (2013) demonstrated the critical role of timeliness in the equality of information access among 
investors. They asserted that the absence of timeliness could lead some groups of investors (well-informed ones) to be better positioned than other groups (less-informed investors) as a result of private information obtained from resources other than the disclosed financial statements.

Consequently, the timeliness of financial reporting influences the behavior of investors and represents one of the key determinants of capital market efficiency. This explains the importance of examining FST, especially in emerging countries. Investors may consider the early or late issuance of statements as a good or bad indicator of company performance, respectively. However, the early or late issuance of financial statements may be attributed to management behavior or "opportunistic management." Management may accelerate or decelerate the issuance of financial statements to accomplish specific interests. This implies that management may manipulate earnings to achieve certain interests that can be realized by either accelerating or decelerating the issuance of financial statements.

\subsection{Earnings management and timeliness of corporate financial statements}

Earnings represent one of the most crucial indicators of firm performance for readers of financial statements, because they include information related to the managerial capabilities and determine the contribution of management to firm profits. Due to the informative characteristics of earnings, many executives are encouraged to engage in earnings management (Lee and $\mathrm{Lu}, 2015$ ). 
Earnings management has been a hot research topic and an international phenomenon prevalent in developing and developed countries, as it has been discovered and studied in most capital markets and accounting systems over the past three decades (Robb, 1998). Earnings management literature has extensively investigated this phenomenon, especially in the context of financial accounting, to determine the managers' incentives, the methods used, the extent to which actual earnings have been altered, and the potential impacts of accounting standards and corporate governance on the extent and nature of earnings management.

Earnings management occurs "when managers use judgment in financial reporting and in structuring transactions to alter financial reports to either mislead some stakeholders about the underlying economic performance of the company or to influence contractual outcomes that depend on reported accounting numbers" (Healy and Wahlen, 1999, p. 368).

However, earnings management researchers and market participants are challenged to discover earnings management attempts because managers who intend to manipulate earnings know they are behaving opportunistically. This, if discovered, can result in financial charges, a bad reputation, or the loss of their job. Therefore, managers select the most efficient methods of earnings management that are more difficult to detect.

On the other hand, researchers document several incentives that motivate management to manipulate earnings. Managers may intend 
to mislead interested parties about real performance or get the highest gains from contracts depending on accounting data, such as compensation and external financing contracts (Healy \& Wahlen, 1999). Further, managers may desire to avoid reporting losses, negative earnings changes, or earnings that cause market disappointments (Degeorge et al., 1999).

Managers employ a variety of earnings management methods. Some of these methods known as accounting earnings management are based on management intervention in the financial reporting process and the accounting rules and regulations, while others known as REM are based on management's intervention in the operating, investing, and financing activities of firms. Contrary to accrual manipulation, REM defines as performing real activities manipulation that depart from normal activities to increase the earnings in the current period by altering the timing or structuring of these activities (Kuo et al., 2014)

Examples of accounting manipulation include the management of accruals, manipulation of the required legal ratios of bad debts, subjective estimation of the fair value of certain assets, subjective measurement of the economic life of long-term assets, and changes to the classification of accounting items. Examples of real manipulation include the sale of assets holding large hidden reserves, acceleration of sales, alteration in shipment schedules, discretionary expenses management, overproduction to reduce cost of goods sold, and early retirement of debt. 
Few studies indicate that both accrual-based earnings management and REM can be used simultaneously to accomplish desired earnings targets (Gaver and Paterson 1999; Barton 2001; Pincus and Rajgopal 2002; Cohen and Zarowin 2010; Badertscher 2011; Zang, 2012). However, some studies demonstrate that some companies prefer to substitute REM for accrual-based earnings management (Braam et al., 2015). Further, (Chung et al., 2015) illustrate that firms may prefer to perform any of the earnings management activities based on their relative costliness. In addition, (Lin and Shen, 2015) examine the trade-offs between REM and accrual -based earnings management regarding the credit risks. They find that accrual -based management associated positively with credit risk, however, REM associated negatively.

Zang (2012) mentioned that accrual-based earnings management and REM strategies differ in the timing of their implementation. REM changes the timing of business transactions; therefore, it should take place during the fiscal year. Further, the outcomes of REM activities are revealed shortly after the year-end. Thus, if the manipulation of real activities causes unexpected results, managers can no longer make adjustments. However, in accrual-based earnings management, managers can adjust the accrual after the year-end but before the earnings announcement date.

Based on the agency theory, there is information asymmetry among managers, shareholders, and readers of financial statements. Management can mislead both shareholders and readers of financial 
statements by manipulating earnings and by enhancing the significance of the earnings. Additionally, management can mislead shareholder understanding by releasing confidential information that supports the required financial targets and, hence, increases the rewards for management (Lee and Lue, 2015).

Consequently, management that manages earnings may influence the timeliness of financial reporting to achieve specific interests. Management may accelerate the announcement of financial statements to gain some privileges, such as the disposition of holding shares. Conversely, management may choose to decelerate the announcement of financial reporting to defer some bad effects of the earnings.

The difference in the timing of the strategies is the core of this study. As REM is implemented during the year, it can influence FST because the real activities cannot be changed after the year-end. The outcomes of REM are achieved after the end of the fiscal year, and these outcomes are either higher or lower than the amount originally expected. Therefore, management is restricted from changing any undesirable effects of the REM activities (Zang, 2012).

This explains why the impact of REM activities on FST is closely examined, and not the opposite relationship. If the earnings management actions are measured by the real activities, the impact of FST on earnings management cannot be examined because management cannot adjust their actions after the end of the year. Additionally, the release of financial statements always comes after 
real earning management activities. Thus, examining the influence of REM on FST, as in this study, is of great importance.

Consequently, this study differs from some prior studies that examined the impact of the earnings announcement date on accrualbased earnings management. These studies postulated that timeliness may influence accrual-based earnings management (Chai and Tung, 2002; Lee and Son, 2009). Below is a brief discussion of both accrualbased earnings management and REM.

\subsubsection{Accruals-based earnings management}

When managing earnings, accounting accruals focus on the changes in the accounting methods or estimates used when presenting transactions in financial statements (Zang, 2012). Accounting accruals are measured as the difference between net income and cash flows from operations (Bartov \& Mohanram, 2003) and are reported because there is no cash received or paid.

There are two types of accruals: accrued revenues and accrued expenses. Accrued revenues are revenues earned, but not yet received in cash or recorded, while accrued expenses are expenses incurred, but not yet paid in cash, or recorded. For example, sale on credit creates sales revenues on the income statement and accrued revenues in the form of receivables on the balance sheet. Further, services rendered without the payment of cash create expenses on the income statement and accrued expenses in the form of payables on the balance sheet.

Extensive literature focuses on accounting accruals when examining earnings management (e.g. Schipper, 1989; Healy and 
Wahlen, 1999; Fields et al., 2001). Therefore, accrual-based measures are used as a proxy for earnings management. However, few studies have investigated the manipulation of real activities.

\subsubsection{REM}

Prior studies have heavily emphasized accrual-based earnings management. However, these studies neglected how managers can also achieve certain earnings targets by manipulating real activities (Lee and $\mathrm{Lu}, 2015$ ). In this regard, (Doukakis, 2015) reveals that while there are extensive studies examine the effects of IFRS adoption on accrual -based earning management, few studies investigate these effects on REM. Management can intervene in the financial statements process through not only their discretion and judgment regarding accounting choices, estimates, and methods, but also their operational decisions (Roychowdhury, 2006; Kothari et al., 2015). The discretion of management to alter the accounting methods represents the key point in recognizing the manipulation of earnings (Cupertino et al., 2015).

REM has been defined and described in accounting literature by several authors. Zang $(2012,676)$ defines REM as “...a purposeful action to alter reported earnings in a particular direction, which is achieved by changing the timing or structuring of an operation, investment, or a financing transaction..." Further, Roychowdhury (2006, 383) describes real manipulation as “...departures from normal operational practices, motivated by managers' desire to mislead at least some stakeholders into believing certain financial reporting goals 
have been met in the normal course of operations." Additionally, Chen et al. (2010) refer to REM as managers' opportunistic timing and structuring of operating, investing, and financing transactions to affect reported earnings in a particular direction. Finally, Gunny $(2010,855)$ documents that "real earnings management occurs when managers undertake actions that deviate from the first best practice to increase reported earnings."

Accordingly, REM represents the deviation from normal business operations with the intention to mislead the stakeholders on recognizing the accurate economic performance through altering the timing and the scope of operation decisions (Ge and Kim, 2014).

Many researchers argue that managers may prefer to engage in REM activities rather than accrual-based earnings management (Healy and Wahlen, 1999; Dechow and Skinner, 2000; Graham et al., 2005; Cohen and Zarowin, 2010). This may be attributed to the increased scrutiny faced by the accruals discretions from auditors and regulators. Auditors and regulators are more unlikely to detect and restrain real manipulation activities (Enomoto et al., 2013; Lee and Lu, 2015). However, REM could be more costly with respect to future firm cash flows and more difficult for stakeholders to detect because REM is easier to camouflage as normal activities compared to accrual-based earnings management (Enomoto et al., 2013).

Following Roychowdhury (2006), the current study focuses on the abnormal values of cash flows from operation and production costs to examine the level of REM. Consequently, two manipulation methods 
are discussed to examine REM: sales manipulation and production cost manipulation. These methods are illustrated in the following section.

\subsubsection{Sales manipulation}

When managers work temporarily to change sales volumes during a specific fiscal period to manage earnings in a desired direction, regardless of negative consequences, they are manipulating sales (Coulten et al., 2005; Roychowdhury, 2006). Managers can use two different instruments to manipulate sales upward: price discounts or easier credit terms. Cutting prices can generate new sales or borrow sales from the next fiscal period into the current period, and thus increase the total earnings, which is the objective of cutting prices (Roychowdhury, 2006). Easier credit terms can increase sales volumes. For example, when managers announce to sell on credit, increase the period of credit repayment, or reduce or eliminate the interest paid on credit sales, retailers consider these easier credit terms as a chance to buy more, which in turn, increases sales volume and total earnings.

Overall, earnings management through sales manipulation is considered REM because managers change the normal operating activity of sales by reducing sales prices more than normal and providing unusual credit terms to manage earnings to a desired level. 


\subsubsection{Production cost manipulation}

Production cost manipulation occurs when managers decide to overproduce products or services rather than meet expected demand (Roychowdhury, 2006). The objective is to reduce the cost of goods sold or cost of services rendered by spreading the fixed overhead costs across a large number of units produced or services rendered. The lower production costs per unit improves the operating margins, and thus increases net income, as long as the reduction in fixed costs per unit due to overproduction is not offset by any increase in the marginal cost per unit (Gunny, 2010). Therefore, managers tend to lower the cost of goods sold through overproduction to boost earnings (Lee and Lu, 2015).

\subsection{Egyptian context}

Egypt provides a proper context to examine FST. The Egyptian Accounting Standards (EAS) discuss the timeliness of financial reporting through the Standard 1, Article No. 43. This article states that "If unnecessary delay in releasing the financial statements has been happened, the information may lose their relevance so management need to balance the relevance of providing the statements in a timely manner and to provide reliable information. To provide timely information it may lead to release statements without all aspects of financial operations or other events are known, and this weakens the credibility. In contrast, delaying the release of the statements to know all aspects of the information may be significantly reliable but it is little beneficial to users who have been forced to 
make decisions in the lag period. Therefore, to achieve the balance between relevance and credibility, the economic needs of decisionmakers should be dominated. " (EAS NO.1, P. 10).

Some companies release financial statements early, less than 30 days, or close to the legal period, while others release financial statements after the legal period. Therefore, investigating the differences in FST will aid Egyptian regulatory bodies in examining the lag between the date of the end of a financial statement and the date of its release. This enhances the importance of this study, which postulates that the differences in FST may be attributed to REM activities.

Further, in Egypt, most previous studies utilized accounting accruals as a measurement for earnings management. However, few studies discuss REM. This study fills this gap by investigating the impact of REM on FST for Egyptian non-financial companies from 2011 to 2013.

\section{Literature review}

Extant literature on FST has many directions. First, some prior studies examined the impact of timely financial statements as independent variables on stock returns (e.g., Chambers \& Penman, 1984), firm value (e.g., Givoly and Palmon, 1982; Kross and Schroeder, 1984), and earnings management (e.g., Chai and Tung, 2002; Lee and Son, 2009)

Second, other studies investigated the factors that influence FST as dependent variables. Many prior studies examined the determinants 
of FST in developed countries (e.g., Givoly and Palmon, 1982; Bamber et al., 1993; Kinney and McDaniel, 1993; Han and Wild, 1997). However, few studies have investigated this topic in developing countries. While Ezat and El-Masry (2008) investigated the timeliness of online reporting for Egyptian companies, they did not investigate the timeliness of releasing financial statements. Additionally, Akle (2011) examined theoretically, but not empirically, the legal framework of financial reporting timeliness in Egypt. Thus, this study extends these studies by investigating empirically the impact of REM on FST.

Additionally, the relationship between earnings management and FST is rarely investigated for developed or developing countries. However, the impact of REM on FST (to the best of the author's knowledge) has not been examined extensively. Therefore, this study contributes to accounting literature by studying such relationships in Egypt.

Some prior studies explored the determinants of FST. Davies and Whittred (1980) sought to shed additional light on corporate reporting timeliness behavior in Australia and its determinants from 1972 to 1977. An unrestricted random sample of 100 industrial and commercial companies listed on the Australian Associated Stock Exchanges revealed that size is the only determinant of total reporting timeliness.

Frost and Pownall (1994) compared domestic and foreign firms listed in both the United States and United Kingdom regarding the 
frequency and timing of accounting disclosure in 1989. Further, the study examined the relationship between the frequency and timing of accounting disclosure. The results indicated that firm size, domicile, and U.S. exchange listing were associated significantly with the sample firms' frequency and timing of accounting disclosure in both countries.

Owusu-Ansah and Leventis (2006) studied the impact of six variables on timely annual financial reporting. The study sample included 95 non-financial companies listed on the Athens Stock Exchange (ASE) in 1999. The results showed that large companies, service companies, and companies audited by the "Big 4" audit firms had shorter final reporting lead-times.

Turel (2010) established the influence of company characteristics on the FST for 211 non-financial companies listed on the Istanbul Stock Exchange in 2007. The study found that the FST increased by reporting net income, having standard audit opinions, and operating in the manufacturing industry, while companies audited by the Big 4 released their financial statements later.

In Malaysia, Hashim et al. (2013) employed a sample consisting of 200 companies from different sectors listed on the Bursa Malaysia in 2007 to demonstrate the determinants of corporate reporting timeliness. The study found that the lead time to publish financial statements is four days earlier than the regulated 121 days. Additionally, the study indicated that only two variables, namely the 
company size and audit duration, had a significant relationship with corporate reporting timeliness.

The focus of this study is to explore the relationship between FST and REM. Few studies have addressed such a relationship. For example, Chai and Tung (2002) investigated whether firms that release earnings reports later than expected engage in earnings management. The study compared the discretionary accruals of a sample of late reporters with those of a sample of non-late reporters for all NYSE, ASE, and NASDAQ companies from 1991 to 1994 in the USA. The findings document that the managers of companies that report earnings late have a higher incentive to use income-decreasing accruals than do managers of companies that report earnings earlier. They do this to enhance future profits and maximize their bonuses.

Lee and Son (2009) argued the importance of auditors in creating an association between total report lag and earnings management. The study classified total report lag into two times: the audit report lag as the time elapsed between the fiscal year-end and the date the audit report was signed, and the discretionary report lag as the time elapsed between the date the audit report was signed and the date of the earnings release. Collecting data from 2001 to 2004 available in COMPUSTAT and Audit Analytics yielded 10191 observations, and provided empirical evidence for the association between total report lag and earnings management. This drives the conclusion that less earnings management by late reporters is attributable to auditors rather than management. 
Aubert (2009) examined both statutory annual financial disclosures in France, specifically the earnings announcement date and the full financial statement release date. Among other variables, the study examined whether earnings management measured by discretionary accrual has an influence on FST. The results indicated that earnings management does not impact the earnings announcement date. However, firms delaying the release of financial statements are more likely to manipulate discretionary accruals components upward. Further, descriptive statistics indicated that 250 firms published their financial reports on an average of 116.07 days after the fiscal yearend.

Accordingly, examining the relationship between FST and REM is still in its infancy. To date, no studies (to the best of the author's knowledge) in the Egyptian context introduce the impact of REM on FST. This study aims to fill this gap by investigating empirically such a relationship for Egyptian non-financial companies from the period of 2011 to 2013.

\section{Hypothesis Formulation}

\subsection{The relationship between REM and FST}

The link between REM and FST can be determined directly and indirectly. Some hypothesize that the late issuance of financial statements may be due to having a qualified audit report. In this case, there is more negotiation between the auditor and management, which increases the length of time before issuance. Givoly and Palmon (1982) emphasized that the length of the audit process is one of the 
most important determinants of timeliness of the earnings announcement, as most of the companies release their earnings after completing the audit and issuing the audit report (Reza and Poudeh, 2014). Therefore, the audit report, including either an un-qualified or a qualified opinion, is examined as a control variable in this study.

Additionally, the possible association between real management activities and FST can be derived from the time consumed and the effort required by the auditors of Egyptian companies to avoid the risk of signaling bad news, represented in a high level of earnings management. Auditors may direct more attention to REM activities and spend more time assuring the level of sales and production cost manipulations and, as proxies for REM, allocate more effort to safeguard their reputations and increase their liability toward investors. The time consumed in auditing increases the time to release financial statements. Hence, companies engaged in REM are likely to extend the time of releasing their financial statements. This view is consistent with Lee and Son (2009) who attributed such results to the increasing effort performed by auditors to scrutinize earnings management activities. The time consumed and effort performed by the auditor is represented as the auditor tenure variable, which signifies engagement between the auditor and his clients for three or more years. Therefore, this study includes audit tenure as a control variable in the research model.

Moreover, many studies have investigated the factors that lead to the delay of earnings announcements. Chai and Tung (2002) argued 
that the early announcement of earnings is related to good news, and late announcement to bad news. Additionally, Givoly and Palmon (1982) and Chambers and Penman (1984) stated that stock prices are

affected by earnings announcement timeliness. Further, Trueman (1990) illustrated that more time should be spent decreasing bad news through accruals manipulation, which leads to delaying bad news announcements. Chai and Tung (2002) stated that political pressure may play a critical role in delaying earnings announcements. Companies that are subjected to high political pressure may delay their announcements. This was confirmed by Han and Wang (1998) who mentioned that petroleum companies tended to decrease declaring income during the Gulf Crisis in 1990 and, as a result, delayed the announcement of their earnings.

As the timeliness of earnings announcements is the same as the FST in Egypt, and because the timeliness of earnings announcements is one of the indicators for positive or negative accrual discretionary and real activities as proxies for earnings management, it can be postulated that earnings management activities influence FST. Based on the above argument, the following hypothesis can be derived:

\section{$H_{1}$ : There is a significant relationship between FST and REM.}

\subsection{Control variables}

\subsubsection{Size}

Large companies are continuously scrutinized by the public, which increases the pressure to disclose timely information. This implies that company size is associated positively with FST. However, previous 
studies have yielded mixed results. For example, Davies and Whittred (1980) and Rahmawati et al. (2013) reported a negative relationship between company size and timeliness, while Hashim et al. (2013) found a positive relationship. However, Courtis (1976) failed to find any significant relationship between company size and timeliness. Therefore, company size is an important variable to study the association with the FST.

\subsubsection{Leverage}

The association between leverage and FST is vague. Some studies argued that highly leveraged companies tend to accelerate releasing their financial statements due to the increased monitoring costs from the pressure of debt holders to report promptly so they can reassess the company's financial performance and position (Owusu-Anash, 2000, Hashim et al., 2013). Other studies indicated that highly leveraged companies take more time to issue their financial statements (Carslaw and Kaplan, 1991; Rahmawati et al., 2013). This may be attributed to the willingness of these companies to delay the presentation of their bad performance. Accordingly, leverage will have a significant impact on the timeliness of financial statements.

\subsubsection{Incidence of loss}

The sign of loss is an indicator of bad news for companies. Some companies experiencing loss are likely to accelerate issuing their financial statements to reduce potential litigation costs (Skinner, 1994). Accordingly, the incidence of loss would be associated negatively with FST. Conversely, companies experiencing loss may 
tend to delay the release of their financial statements to defer the bad news from investors until other companies release their statements. Based on this argument, there will be a positive relationship between incidence of loss and FST (Aubert, 2009).

\subsubsection{Auditor type}

It is assumed that companies audited by the Big 4 audit firms will release their financial statements more quickly than those audited by other audit firms. The Big 4 audit firms intend to maintain their reputation; therefore, they complete their audit work quickly which leads to shorten the FST (Hashim et al., 2013). Additionally, the Big 4 audit firms are characterized by a large staff, greater experience, and economies of scale for the provision of audit services, which lead to improving the FST. Accordingly, it will be expected to find a positive relationship between the companies audited by the Big 4 audit firms and FST.

\subsubsection{Audit report}

Types of audit report opinions, whether unqualified or qualified, may impact FST. Audit reports with qualified opinions may increase the time to release financial statements because auditors need to discuss many issues with management. Additionally, auditors must then adjust the issues related to the qualification (Soltani, 2002; Rahmawati et al., 2013). Consequently, companies with qualified audit opinions may issue their financial statements later than those with unqualified opinions. 


\subsubsection{Auditor tenure}

Audit tenure refers to the number of continuous years that the auditor is engaged with a client. It assumes that in the first years of engagement, an auditor may exert more time or effort auditing a company and, hence, this will increase the time to release financial statements. However, when the auditor is engaged with the company for more than one year continuously, they will have experience of the company and this will shorten the time to issue financial statements. Therefore, as audit tenure increases in one company, the FST will increase.

\section{Sample and Variables measurement}

\section{1 Sample}

The sample in this study covered the period from 2011 to 2013 for all non-financial Egyptian companies listed on the Egyptian Exchange. This study excludes 42 financial companies and banks, as done by Owusu-Anash (2000) and Rahmawati et al. (2013) because of difficulties encountered when calculating the REM models. Eight companies were also excluded from the sample due to the unavailability of data. This led to a final sample consisting of 170 companies with 509 observations. The FST for the Egyptian companies was obtained from their official announcement on the Egyptian Exchange website.

\subsection{Research model}


This study conducted three ordinary least squares (OLS) regression models to test the research hypothesis. The first model explored the impact of REM on the total FST in Egypt. The second and third models identified the relationships between REM and the early and late FST for the Egyptian companies. REM was measured by two different models, which are illustrated as follows:

\section{REM models:}

Roychowdhury (2006) is the pioneer study that presents three methods of REM and Gunny (2012) added a new method. The four methods as presented as follows:

(1) Sale of assets that hold large unrealized capital gains/losses;

(2) Sales manipulation through abnormal discounts or significant easy credit terms or easy sales contracts;

(3) Reduction of discretionary expenditures, such as R\&D, advertising, and maintenance; and,

(4) Overproduction to lower cost of goods sold by allocating more overhead to inventory and less to cost of goods sold.

Roychowdhury (2006) and Gunny (2012) use the following proxies:

- Abnormal capital gains/losses to express the sale of assets that hold large unrealized capital gains/losses.

- Abnormal cash flows from operations (CFO) to express sales manipulation. 
- Abnormal discretionary expenses to express the reduction of discretionary expenditures.

- Abnormal production costs to express overproduction to lower the cost of goods sold.

This study uses both the sales manipulation and production cost manipulation methods to investigate REM. The two main models used to measure these manipulation methods are as follows:

\section{Model A: The abnormal CFO (REM using sales manipulation):}

$\boldsymbol{C F O}=\boldsymbol{\beta O}(1 /$ TAt -1$)+\boldsymbol{\beta} 1($ Sales $)+\boldsymbol{\beta} 2(\Delta$ Sales $)+\boldsymbol{\varepsilon}$

\section{where:}

CFO: cash flows from operations $\quad \boldsymbol{\beta}_{0}=$ the intercept TAt-1: total assets of prior year Sales: current year sales ( $\Delta$ Sales): change in sales from prior year $\varepsilon$ : The residual value (All variables are scaled by prior year total assets)

\section{Model B: The abnormal production costs (REM using production} costs manipulation)

$\operatorname{Prod}=\beta 0(1 /$ TAt -1$)+\beta 1($ Sales $t)+\beta 2(\Delta$ Sales $t)+\beta 3(\Delta$ Sales $t-1)+\varepsilon$

where:

Prod: Production costs $=(\mathrm{COGS}+\Delta$ Inventory $)$

COGS: Cost of goods sold

$\Delta$ Inventory: Change in inventories from prior year

$\boldsymbol{\beta}_{0}$ : Intercept

TAt-1: Total assets of prior year

Sales: Current year sales

$\Delta$ Sales t: Change in sales from prior year

$\Delta$ Sales t-1: Change in sales of prior year from the year before $\boldsymbol{\varepsilon}$ :

Residual value 
(All variables were scaled by the prior year total assets.)

Then, the residual values (the abnormal amount) of the models were used as proxies for each REM type in the following models:

\section{Model 1.A:}

$T F S T=\boldsymbol{\beta}_{0}+\boldsymbol{\beta}_{1} \boldsymbol{A B C F O}+\boldsymbol{\beta}_{2}$ Size $+\boldsymbol{\beta}_{3} L e v+\boldsymbol{\beta}_{4} L o s s+\boldsymbol{\beta}_{5} A u d+\boldsymbol{\beta}_{6} T u n+$ $\boldsymbol{\beta}_{7} \mathrm{Opn}+\boldsymbol{\varepsilon}$

where:

TFST $=$ Total FST $\quad \boldsymbol{\beta}_{\mathbf{0}}=$ Intercept

ABCFO = Abnormal (residual) value of CFO used as the first proxy for REM
Size $=$ Company size
Lev $=$ Leverage
Loss $=$ Sign of performance
Aud $=$ Auditor type
Tun $=$ Auditor tenure
Opn = Auditor opinion

\&: Residual value

Model 1.B:

$T F S T=\boldsymbol{\beta}_{0}+\boldsymbol{\beta}_{1}$ ABPROD $+\boldsymbol{\beta}_{2}$ Size $+\boldsymbol{\beta}_{3} L e v+\boldsymbol{\beta}_{4} L o s s+\boldsymbol{\beta}_{5} A u d+\boldsymbol{\beta}_{6} T u n+$ $\boldsymbol{\beta}_{7} O p n+\varepsilon$

where:

ABPROD = Abnormal (residual) value of production costs used as the second proxy for REM.

Model 2.A:

$E F S T=\boldsymbol{\beta}_{0}+\boldsymbol{\beta}_{1} \boldsymbol{A B C F O}+\boldsymbol{\beta}_{2} S i z e+\boldsymbol{\beta}_{3} L e v+\boldsymbol{\beta}_{4} L o s s+\boldsymbol{\beta}_{5} A u d+\boldsymbol{\beta}_{6} T u n+$ $\boldsymbol{\beta}_{7} \mathrm{Opn}+\boldsymbol{\varepsilon}$ 
where:

EFST $=$ Early FST

This study classified the total FST into the two groups of early or late reporters of financial statements. The models related to these groups are presented as follows:

\section{Model 2.B:}

$E F S T=\boldsymbol{\beta}_{0}+\boldsymbol{\beta}_{1}$ ABPROD $+\boldsymbol{\beta}_{2}$ Size $+\boldsymbol{\beta}_{3} L e v+\boldsymbol{\beta}_{4} L o s s+\boldsymbol{\beta}_{5} A u d+\boldsymbol{\beta}_{6} T u n+$ $\boldsymbol{\beta}_{7} O p n+\varepsilon$

\section{Model 3.A:}

$L F S T=\boldsymbol{\beta}_{0}+\boldsymbol{\beta}_{1} \boldsymbol{A B C F O}+\boldsymbol{\beta}_{2}$ Size $+\boldsymbol{\beta}_{3} L e v+\boldsymbol{\beta}_{4} L o s s+\boldsymbol{\beta}_{5} A u d+\boldsymbol{\beta}_{6} T u n+$ $\boldsymbol{\beta}_{7} O p n+\varepsilon$

\section{where:}

LFRT = Late FST

\section{Model 3.B:}

$L F S T=\boldsymbol{\beta}_{0}+\boldsymbol{\beta}_{1}$ ABPROD $+\boldsymbol{\beta}_{2}$ Size $+\boldsymbol{\beta}_{3} L e v+\boldsymbol{\beta}_{4} L o s s+\boldsymbol{\beta}_{5} A u d+\boldsymbol{\beta}_{6} T u n+$ $\boldsymbol{\beta}_{7} O p n+\boldsymbol{\varepsilon}$

\subsection{Measurement of the variables}

\subsubsection{The FST (dependent variable)}

FST was measured as the number of days elapsed from the yearend to the official release of the financial statements. This study classified total FST into two main groups: the first related to companies that report earlier, including all that released their financial statements five days earlier than the preceding year, and the second related to companies that reported later, including all that released their financial statement five days later than the preceding year. The 
cutoff point of five days was applied following Haw et al. (2000) and Chai and Tung (2002).

\subsubsection{The independent variable}

REM and the other control variables were measured using the following proxies illustrated in Table 1.

Table 1: Measurement of the independent and control variables

\begin{tabular}{|c|l|l|}
\hline $\begin{array}{c}\text { Variables } \\
\begin{array}{c}\text { Real earning } \\
\text { management }\end{array}\end{array}$ & Acronym & \multicolumn{1}{|c|}{ Proxy } \\
\hline Company size & Size & $\begin{array}{l}\text { The residual amount of two } \\
\text { different models }\end{array}$ \\
\hline Total assets \\
\hline $\begin{array}{c}\text { Leverage } \\
\text { Incidence of }\end{array}$ & Lev & Total liabilities/Total assets \\
\hline Auditor Type & Aud & $\begin{array}{c}1=\text { if the company report loss } \\
\text { before extraordinary items. } \\
0=\text { otherwise. } \\
1=\text { big } 4 \\
0=\text { others }\end{array}$ \\
\hline Audit Report & Opn & $\begin{array}{l}1=\text { unqualified } \\
0=\text { Qualified }\end{array}$ \\
\hline Auditor tenure & Tun & $\begin{array}{c}1=\text { if the auditor engaged } \\
\text { with the client for more than or } \\
\text { equal three years. } \\
0=\text { if not }\end{array}$ \\
\hline & &
\end{tabular}

\section{Data analysis and results}

\subsection{Model 1 results}

\subsubsection{Descriptive results}

Table 2 exhibits the descriptive findings for the FST, the REM measured by Models A and B, and the control variables. Table 2 shows that Egyptian companies take an average of 82.83 days to release their financial statements, with a minimum of 9 days and a maximum of 270 days. This implies that most Egyptian companies are 
committed to the legal period of releasing the financial statements. However, some Egyptian companies exceed this legal period.

Moreover, Table 2 indicates that abnormal cash flows (the sales manipulation proxy of REM) ranges from -11.91625 to 9.25532 with a mean of -.0008229 , implying that the sample firms report both a positive and negative abnormal proxy, but tend to report more negative values than positive values. This may mean that the actual cash flows are lower than the expected or normal levels for the majority of the sample firms, or it may indicate that there are some discounts for undertaking REM. Companies that aim to manage their earnings upward are likely to have abnormal low cash flows from operations and, hence, sales manipulation occurs (Cohen and Zarowin, 2008). Accordingly, it can be concluded that Egyptian companies perform some REM activities through sales manipulation.

Table 2 also exhibits that abnormal production costs (the production cost manipulation proxy of REM) ranges from -13.75 to 10.448 with a mean of .0122769 , implying that the sample firms report positive abnormal production costs of 0.01227 on average. This indicates that the total sample tends to undertake overproduction to manage earnings upward. Companies that aim to manage their earnings upward may have abnormally high production costs. This is initial evidence of the existence of REM by the overproduction of Egyptian companies.

Additionally, Table 2 shows that the average size of the Egyptian companies is L.E. 2833722803 with a relatively low leverage 
percentage of 43 per cent. Further, most of the Egyptian companies (82.5 per cent) report profits and are audited by audit firms that are not the Big 4 (67 per cent) that are engaged with the companies for three or more years (79 per cent) and issue un-qualified audit reports (56 per cent).

Table 2: Descriptive results for dependent, independent and control variables for model (1)

\begin{tabular}{|c|c|c|c|c|}
\hline Variables & Mean & Min. & Max. & Std. Dev. \\
\hline \multicolumn{5}{|c|}{ Panel A: Dependent V. } \\
\hline Total FST & 82.83 & 9 & 270 & 37.535 \\
\hline \multicolumn{5}{|c|}{ Panel B: Independent V. } \\
\hline $\begin{array}{l}\text { ABCFO } \\
\text { REM (Model A) }\end{array}$ & -.0008229 & -11.91625 & 9.25532 & 1.00030707 \\
\hline $\begin{array}{l}\text { ABPROD } \\
\text { REM (Model B) }\end{array}$ & .0122769 & -13.75221 & 10.44815 & 1.02306907 \\
\hline \multicolumn{5}{|l|}{ Panel C: Control V. } \\
\hline Size & 2833722803 & 20246516 & 68222900000 & 8114403695.214 \\
\hline Lev & .42860 & .003 & 2.261 & .261488 \\
\hline Dummy V. & Frequency & & $\%$ & \\
\hline $\begin{array}{l}\text { Loss: } \\
1=\text { if the company } \\
\text { report loss. } \\
0=\text { otherwise }\end{array}$ & $\begin{array}{l}89 \\
420\end{array}$ & & $\begin{array}{l}17.5 \\
82.5\end{array}$ & \\
\hline $\begin{array}{c}\text { Aud } \begin{array}{c}1=\text { Big4 } \\
0=\text { Not Big4 }\end{array} \\
\end{array}$ & $\begin{array}{l}169 \\
340 \\
\end{array}$ & & $\begin{array}{l}33.2 \\
66.8\end{array}$ & \\
\hline $\begin{array}{l}\text { Tun } \\
1=\text { The auditor } \\
\text { engaged with the } \\
\text { client for more } \\
\text { than or equal three } \\
\text { years. } \\
0=\text { otherwise }\end{array}$ & 106 & & 20.8 & \\
\hline $\begin{array}{l}\text { Opn } \\
\text { 1=Un-qualified } \\
0=\text { Qualified }\end{array}$ & $\begin{array}{l}286 \\
223\end{array}$ & & $\begin{array}{l}56.2 \\
43.8\end{array}$ & \\
\hline
\end{tabular}




\subsubsection{Univariate analysis results}

Table 3 shows the correlation matrix between the variables. According to the correlation coefficient, there is no multicollinearity between variables as all the correlation coefficients are below 0.75.TFST is correlated negatively with both ABCFO and ABPROD. Moreover, TFST is correlated significantly with firm size, leverage, and audit opinion.

Table 3: Correlation matrix of study's variables

\begin{tabular}{|l|l|l|l|l|l|l|l|l|}
\hline & $(\mathrm{B})$ & $(\mathrm{C})$ & $(\mathrm{D})$ & $(\mathrm{E})$ & \multicolumn{1}{c|}{$(\mathrm{F})$} & \multicolumn{1}{c|}{$(\mathrm{G})$} & \multicolumn{1}{c|}{$(\mathrm{H})$} & \multicolumn{1}{c|}{$(\mathrm{I})$} \\
\hline$(\mathrm{A})$ & $-.110^{*}$ & $-.149 * *$ & $.147^{* *}$ & $.228^{* *}$ & .054 & -.053 & -.044 & $-.333^{* *}$ \\
\hline (B) & & & $.283^{* *}$ & $.118^{* *}$ & -.077 & $.116^{* *}$ & $-.112^{*}$ & -.011 \\
\hline (C) & & & -.034 & .061 & .005 & -.073 & .053 & .007 \\
\hline (D) & & & & $.225^{* *}$ & -.013 & $.426^{* *}$ & $.143^{* *}$ & -.044 \\
\hline (E) & & & & & $.263^{* *}$ & $.113^{*}$ & $.097^{*}$ & $-.121^{* *}$ \\
\hline (F) & & & & & & -.018 & .045 & -.083 \\
\hline (G) & & & & & & & 061 & $.192^{* *}$ \\
\hline (H) & & & & & & & & -.004 \\
\hline
\end{tabular}

Note: A: TFST, B: ABCFO, C:ABPROD, D: Size, E: Lev, F: Loss, G: Big 4, H: Tun, I: Opn.

\subsubsection{Multivariate analysis results and discussion}

\section{Model 1 results:}

Table 4 presents the association between total FST and REM for both models used to measure REM. 
Table 4: OLS results of the association between Total FST and the two models of REM

\begin{tabular}{|c|c|c|c|c|c|c|c|c|c|c|}
\hline \multicolumn{6}{|c|}{ Model 1.A (Sales Manipulation) } & \multicolumn{3}{|c|}{$\begin{array}{c}\text { Model 1.B (Production costs } \\
\text { manipulation) }\end{array}$} & \multirow[b]{2}{*}{ Tol. } & \multirow[b]{2}{*}{$V I F$} \\
\hline & Coef. & $\begin{array}{l}\mathrm{T} \\
\text { Statistic }\end{array}$ & $P$ value & Tol. & VIF & Coef. & $\begin{array}{l}\mathrm{T} \\
\text { Statistic }\end{array}$ & $P$ value & & \\
\hline REM & $-.197 * * *$ & -4.625 & .000 & .884 & 1.131 & $-.147 * * *$ & 3.596 & .000 & .982 & 1.018 \\
\hline Size & $.186 * * *$ & 3.932 & .000 & .713 & 1.403 & $.145 * * *$ & 3.098 & .002 & .751 & 1.332 \\
\hline Lev & $.199 * * *$ & 4.614 & .000 & .859 & 1.164 & $.168 * * *$ & 3.817 & .000 & .848 & 1.179 \\
\hline Loss & -.033 & -.799 & .424 & .914 & 1.094 & -.001 & -.021 & .983 & .903 & 1.108 \\
\hline Aud & -.069 & -1.509 & .132 & .772 & 1.296 & -.059 & -1.271 & .204 & .768 & 1.302 \\
\hline Tun & $-.111 * * *$ & -2.714 & .007 & .950 & 1.053 & $-.089 * *$ & -2.166 & .031 & .972 & 1.028 \\
\hline Opn & $-.296 * * *$ & -7.113 & .000 & .925 & 1.081 & $-.294 * * *$ & -6.974 & .000 & .929 & 1.076 \\
\hline $\begin{array}{l}\mathrm{P} \\
\text { value }\end{array}$ & .000 & & & & & 0.000 & & & & \\
\hline $\begin{array}{l}\text { F- } \\
\text { Ratio }\end{array}$ & 17.898 & & & & & 16.251 & & & & \\
\hline $\begin{array}{l}\text { Adj. } \\
\mathrm{R}^{2}\end{array}$ & $\begin{array}{ll}18.9 & \text { Per } \\
\text { cent } & \end{array}$ & & & & & $\begin{array}{l}\text { 17.6 Per } \\
\text { cent }\end{array}$ & & & & \\
\hline
\end{tabular}

There were no serious multicollinearity issues among the independent variables, as all VIF values are below 10, and the tolerance values are greater than 0.1 (Field, 2009). Both regression models are statistically significant at the 1 per cent level with an adjusted R2 of 18.9 per cent for Model 1.A and 17.6 per cent for Model 1.B. Models 1.A and 1.B illustrate that FST is negatively associated with ABCFO (the proxy of REM in Model 1.A) and ABPROD (the proxy of REM in Model 1.B) at a confidence level of 99 per cent. This implies that Egyptian listed companies are less likely to manage earnings when the time elapsed from the date of the balance sheet to the release date of the financial statements increases. This can be explained by the signaling theory. When companies tend to manage earnings upward, they are engaged in REM activities. One 
way to fulfill upward earnings is through sales manipulation by increasing price discounts or providing permissive credit terms, which ultimately lower the ABCFO. Another way to fulfill upward earnings is through overproduction by lowering the fixed costs per unit by spreading the fixed overhead costs over a large number of production units, which ultimately increases the ABPROD.

Consequently, companies performing REM activities, through either sales manipulation or production cost manipulation, are more likely to accelerate the release of their financial statements to signal the boost in their earnings to investors. On the other hand, when companies are willing to manage earnings downward, they engage in REM activities, such as underproduction, and are more likely to delay releasing their financial statements to avoid signaling bad news to their investors. Therefore, based on the signaling theory, REM activities performed by Egyptian companies have a significant impact on their FST.

Another explanation for the association between REM and total FST is the difficulty auditors may have in discovering REM activities (Zang, 2012; Enomoto et al., 2013; Lee and Lu, 2015). REM is activities performed by management during the year through the normal course of operations, and their impact on the direction of earnings is difficult to discover. This may accelerate the timeliness of issuing the auditor report because the auditor cannot discover the REM activities easily and finalizes the audit work more rapidly. This, in turn, accelerates the FST. 
Based on the above justifications, $\mathrm{H} 1$ is supported.

Additionally, all control variables except loss incidence and audit types have significant relationships with the total FST. Both models of measuring REM have the same results for the control variables. Models 1.A and 1.B reported that large Egyptian companies with high levels of leverage are engaged with their auditors, who issue qualified reports, for fewer than three years and are associated positively with the total FST at a confidence level of 99 per cent.

Large Egyptian companies may conduct complicated activities that require more audit time, which increases the time to release financial statements. This result is consistent with Hashim et al. (2013). Additionally, highly leveraged Egyptian companies extend their FST to delay signaling bad news until other companies release their financial statements. This result is consistent with Carslaw and Kaplan (1991) and Rahmawati et al. (2013). Further, Egyptian companies that are audited by auditors who were engaged with them for less than three years and issued qualified opinions extended the release of their financial statements. This may attribute to the time consumed, effort performed, or lack of experience in the audit process. Such results are compatible with Soltani (2002) and Rahmawati et al. (2013).

The results demonstrated by each model support each other, indicating creditability in the results of the models used to measure REM activities. 


\subsection{Models 2 and 3 results}

\subsubsection{The descriptive results}

This study conducted additional statistical analysis to confirm the results obtained from Model 1 and add more depth to the relationship between REM and FST. Tables 5 and 6 present the descriptive results for early and late reporter companies, respectively. The average days elapsed to release financial statements for early reporter companies is 72 , which indicates that most of the early reporter companies are committed to the legal period of issuing financial statements in Egypt. However, late reporter companies take on average 100 days to release their financial statements, indicating that most of the late reporters exceed the legal period of issuing financial statements in Egypt.

It can also be noted that both early and late reporters perform REM activities to some extent. As show in Table 5, the means of the abnormal values for Models A and B are negative. For Model A, the mean of the ABCFO is -0.01987 , which indicates that actual cash flows are lower than the expected or normal level for the majority of early reporter companies due to REM to increase earnings. This indicates that early reporter Egyptian companies are engaged in REM activities. Similarly, for Model B, the mean of the ABPROD is 0.0807864 , which implies that most of the late reporter companies perform underproduction activities to manage earning downward. Therefore, it can be concluded that early reporter Egyptian companies are more likely to manipulate sales upward when performing REM activities rather than performing overproduction actions. 
According to table 6, the means of the abnormal values for Models $\mathrm{A}$ and $\mathrm{B}$ for late reporter companies are positive. For Model A, the mean of the ABCFO is .0753. This indicates that late reporter companies are less likely to manipulate sales to manage earnings. Likewise, for Model B, the mean of the ABPROD is 0.0451. This implies that late reporter companies perform overproduction activities to manage earnings. Therefore, late reporter Egyptian companies are more likely to manage earnings upward through overproduction actions rather than by manipulating sales.

The comparison between early and late reporter companies demonstrates that early reporter companies are larger and less leveraged than late reporter companies. However, both companies report nearly the same incidence of loss. Further, the majority of both early and late reporter companies are audited by non-Big 4 companies that are engaged for three or more years and issued qualified audit reports. 
Table 5: Descriptive results for dependent, independent and control variables for early reporter (Model 2)

\begin{tabular}{|c|c|c|c|c|c|}
\hline Variables & Number & Mean & Min. & Max. & Std. Dev. \\
\hline & \multicolumn{5}{|c|}{ Panel A: Dependent V. } \\
\hline Early FST & 187 & 72.07 & 12 & 239 & 28.652 \\
\hline \multicolumn{6}{|c|}{ Panel B: Independent V. } \\
\hline $\begin{array}{l}\text { ABCFO } \\
\text { REM (Mode }\end{array}$ & & -.01987 & -5.231 & 8.711 & .883941 \\
\hline $\begin{array}{l}\text { ABPROD } \\
\text { REM (Mod }\end{array}$ & & -.0807864 & -13.75221 & 2.07744 & 1.10291013 \\
\hline \multicolumn{6}{|c|}{ Panel C: Control V. } \\
\hline Size & & 2539840200 & 22645024 & 54964208966 & 8114403695.2 \\
\hline Lev & & .42860 & .003 & 1.32 & .4159 \\
\hline Dummy V. & & Frequency & & $\%$ & \\
\hline $\begin{array}{l}\text { Loss: } \\
1=\text { if the cor } \\
\text { loss. } \\
0=\text { otherwis }\end{array}$ & any report & $\begin{array}{l}36 \\
151 \\
\end{array}$ & & $\begin{array}{l}19.3 \\
80.7\end{array}$ & \\
\hline \multicolumn{2}{|c|}{$\begin{array}{l}1=\operatorname{Big} 4 \\
0=\text { Not Big } 4\end{array}$} & \multicolumn{2}{|l|}{$\begin{array}{l}62 \\
125 \\
\end{array}$} & \multicolumn{2}{|l|}{$\begin{array}{l}33.2 \\
66.8 \\
\end{array}$} \\
\hline \multicolumn{2}{|c|}{$\begin{array}{l}\text { Tun } \\
1=\text { The auditor engaged } \\
\text { with the client for more } \\
\text { than or equal three years. } \\
0=\text { otherwise. }\end{array}$} & \multicolumn{2}{|l|}{149} & \multicolumn{2}{|l|}{79.7} \\
\hline \multicolumn{2}{|c|}{$\begin{array}{l}\text { Opn } \\
1=\text { Un-qualified } \\
0=\text { Qualified }\end{array}$} & \multicolumn{2}{|l|}{$\begin{array}{l}117 \\
70 \\
\end{array}$} & $\begin{array}{l}37.4 \\
62.6 \\
\end{array}$ & \\
\hline
\end{tabular}


Table 6: Descriptive results for dependent, independent and control variables for Late reporter (Model 3)

\begin{tabular}{|c|c|c|c|c|c|}
\hline \multirow[t]{2}{*}{ Variables } & Number & Mean & Min. & Max. & Std. Dev. \\
\hline & \multicolumn{5}{|c|}{ Panel A: Dependent V. } \\
\hline Late FST & 158 & 100.24 & 14 & 270 & 44.062 \\
\hline \multicolumn{6}{|c|}{ Panel B: Independent V. } \\
\hline $\begin{array}{l}\text { ABCFO } \\
\text { REM (Mod }\end{array}$ & & .0753 & -11.92 & 7.43 & 1.28020 \\
\hline $\begin{array}{l}\text { ABPROD } \\
\text { REM (Mod }\end{array}$ & & .0451 & -7.03 & 2.59 & .79738 \\
\hline \multicolumn{6}{|c|}{ Panel C: Control V. } \\
\hline Size & & 33162809 & 68222900000 & 3059756028.1 & 8938664577.8 \\
\hline Lev & & .45200 & .006 & 2.261 & .308538 \\
\hline Dummy V. & & Frequency & & $\%$ & \\
\hline $\begin{array}{l}\text { Loss: } \\
1=\text { if the col } \\
\text { report loss. } \\
0=\text { otherwi }\end{array}$ & any & $\begin{array}{l}33 \\
125\end{array}$ & & $\begin{array}{l}20.9 \\
79.1\end{array}$ & \\
\hline $\begin{aligned} & \text { Aud } \\
& 1=1 \\
& 0=\mathrm{I}\end{aligned}$ & Big4 & $\begin{array}{l}46 \\
112\end{array}$ & & $\begin{array}{l}29.1 \\
70.9\end{array}$ & \\
\hline \multicolumn{2}{|c|}{$\begin{array}{l}\text { Tun } \\
1=\text { The auditor engaged } \\
\text { with the client for more } \\
\text { than or equal three } \\
\text { years. } \\
0=\text { otherwise }\end{array}$} & 129 & & 81.6 & \\
\hline \multicolumn{2}{|c|}{$\begin{array}{l}\text { Opn } \\
1=\text { Un-qualified } \\
0=\text { Qualified }\end{array}$} & $\begin{array}{l}68 \\
90\end{array}$ & & $\begin{array}{l}43 \\
57\end{array}$ & \\
\hline
\end{tabular}

\subsubsection{Multivariate analysis results and discussion}

\subsubsection{Model 2 results:}

Table 7 illustrates the association between early reporter Egyptian companies and REM for both models used to measure REM. Both regression models are statistically significant at the level 1 per cent with an adjusted R2 of 16.6 per cent for Model 2.A and 14.8 per cent for Model 2.B. Model 2.A demonstrates that FST for early reporter 
Egyptian companies is negatively associated with $\mathrm{ABCFO}$ (the proxy of REM in Model 2.A) at a confidence level of 99 per cent. Early reporter Egyptian companies are more likely to accelerate the release of their financial statements when earnings are upward to signal the good news to their investors. This result confirms the results obtained from Model 1.A. However, the OLS regression analysis indicates that there is no relationship between FST for early reporter Egyptian companies and ABPROD (the proxy of REM in Model 2.B). This result implies that early reporter companies are more likely to manipulate sales to manage earnings upward than perform overproduction activities, which is illustrated by the descriptive results in Table 5. Both models of early reporter companies indicate that FST for early reporter companies is associated positively with unqualified audit reports only.

Table 7: OLS results of the association between Early FST and the two models of REM

\begin{tabular}{|c|c|c|c|c|c|c|}
\hline \multicolumn{4}{|c|}{ Model 2.A (Sales Manipulation) } & \multicolumn{3}{|c|}{$\begin{array}{c}\text { Model 2.B (Production costs } \\
\text { manipulation) }\end{array}$} \\
\hline & Coef. & $\begin{array}{l}\mathrm{T} \\
\text { Statistic }\end{array}$ & $P$ value & Coef. & T Statistic & $P$ value \\
\hline REM & $-.219 * * *$ & -3.055 & .003 & .021 & .299 & .765 \\
\hline Size & 281 & 3.541 & .001 & .981 & .206 & 2.682 \\
\hline Lev & $.138^{*}$ & 1.915 & .057 & -.185 & .159 & 2.171 \\
\hline Loss & .008 & .111 & .912 & 4.714 & .051 & .729 \\
\hline Aud & .007 & .093 & .926 & $\begin{array}{l}-.001 \\
\end{array}$ & $\begin{array}{l}.009 \\
\end{array}$ & .993 \\
\hline Tun & -.022 & -.323 & .747 & .018 & .257 & .797 \\
\hline Opn & $-.240 * * *$ & -3.474 & .001 & $-.269 * * *$ & -3.843 & .000 \\
\hline $\mathrm{P}$ value & .000 & & & 0.000 & & \\
\hline F-Ratio & 6.334 & & & 5.599 & & \\
\hline Adj. $R^{2}$ & 16.6 Per cent & & & 14.8 Per cent & & \\
\hline
\end{tabular}

Note: *,** and *** indicate significant at 10per cent, 5 per cent and 1per cent, respectively 


\subsubsection{Model 3 results:}

Table 8 shows the association between the late reporter Egyptian companies and REM for both models used to measure REM. Both regression models are statistically significant at the level 1 per cent with an adjusted R2 of 17.7 per cent for the Model 3.A and 15.2for Model 3.B. Model 3.A reveals that FST for late reporter Egyptian companies is related significantly with ABCFO (the proxy of REM in Model 3.A) at a confidence level of 95 per cent. This result implies that late reporter companies tend to delay the issuance of their financial statements when they manage earnings downward to defer the announcement of bad news. This result is consistent with the results obtained from Model 1.A. However, similar to Model 2.B, Model 3.B does not provide any empirical evidence for the impact of ABPROD (the proxy of REM in Model 3.B) on the FST of late reporter companies. This result confirms that late reporter Egyptian companies are more likely to manipulate sales rather than production costs to manage earnings upward.

Both models of late reporter companies demonstrate that the FST for late reporter companies is associated positively with unqualified audit reports and leverage. Only Model 3.B indicates that FST for late reporter companies is associated positively with company size. 
Table 8: OLS results of the association between Late FST and the two models of REM

\begin{tabular}{|c|c|c|c|c|c|c|}
\hline \multicolumn{4}{|c|}{ Model 3.A (Sales Manipulation) } & \multicolumn{3}{|c|}{$\begin{array}{l}\text { Model 3.B (Production costs } \\
\text { manipulation) }\end{array}$} \\
\hline & Coef. & T Statistic & $P$ value & Coef. & T Statistic & $P$ value \\
\hline REM & $-.169 * *$ & -2.282 & .024 & .058 & .771 & .442 \\
\hline Size & -.169 & -2.282 & .132 & $.143 *$ & 1.701 & .091 \\
\hline Lev & $.125 * * *$ & 1.514 & .001 & $.250 * * *$ & 3.223 & .002 \\
\hline Loss & .249 & 3.277 & .454 & -.028 & -.366 & .715 \\
\hline Aud & -.056 & -.750 & .574 & -.060 & -.697 & .487 \\
\hline Tun & -.097 & -1.318 & .190 & -.102 & -1.361 & .176 \\
\hline Opn & $-.268 * * *$ & -3.373 & .001 & $-.248 * * *$ & -3.094 & .002 \\
\hline $\mathrm{P}$ value & .000 & & & 0.000 & & \\
\hline F-Ratio & 5.836 & & & 5.026 & & \\
\hline Adj. $\mathrm{R}^{2}$ & 17.7 Per cent & & & 15.2 Per cent & & \\
\hline
\end{tabular}

Note: *,** and $* * *$ indicate significant at 10 per cent, 5 per cent and 1 per cent, respectively

\section{Conclusions, limitations, and opportunities for further research}

The timeliness of the disclosed information in the financial statements of companies is one of the most important characteristics for investors. Prior studies of developed countries examined the factors that influence FST. However, few studies of developing countries have investigated this concept. Specifically, in Egypt the determinants of FST have not been examined widely.

The concept of earnings management has been largely studied in both developed and developing countries. There are two categories of earnings management: accrual-based earnings management and REM. However, most previous studies concentrated mainly on accrual-based 
earnings management and REM has not been given sufficient attention, especially in developing countries.

Therefore, this paper seeks to fill this gap by investigating empirically the influence of REM on FST for Egyptian non-financial listed companies from 2011 to 2013. This signifies the main contribution of this study, as the relationship between REM and FST is not examined widely either on the developed or developing countries.

The descriptive results indicate that, on average, Egyptian companies spend 82 days to release their financial statements, which demonstrates that most Egyptian companies are committed to releasing their financial statements within the legal period. The descriptive results also show that Egyptian companies are engaged in REM activities. When Egyptian companies manage earnings upward, they perform sales and production cost manipulation activities.

This study conducted three OLS models to investigate the relationship between FST and REM. The first model examined the association between REM and the total FST, while the second and third models examined the relationship between REM and the early and late reporter Egyptian companies, respectively. Furthermore, this study used two models to measure REM: the first used abnormal cash flow from operations, which indicates a sales manipulation, and the second used abnormal production costs, which indicates overproduction or underproduction. The empirical results reveal that Egyptian companies are likely to accelerate the release of their 
financial statements when they perform REM to manage earnings upward to impart a positive impression. Further analysis indicates that early reporter Egyptian companies are likely to manage earnings upward, while late reporter Egyptian companies delay the release of their financial statements when they manage earnings downward to defer bad implications from the market.

There are some limitations of this study. First, the unavailability of some data restricted the sample of the study. Future research may extend the sample to examine the FST of Egyptian companies on a larger scale. Second, this study concentrated mainly on the relationship between FST and REM. Future research may include more variables, such as audit-related variables, to investigate the key determinants of FST. Finally, this study examined REM activities and their impact on FST. Future research may also examine accrual-based earning management activities and their impact on FST, and compare these results with those for REM. 


\section{References:}

Abdelsalam, O.H. and Street, D.L. (2007), "Corporate governance and the timeliness of corporate internet reporting by UK listed companies', Journal of International Accounting, Auditing and Taxation, Vol. 16 No.2, pp. 111-30

Accounting Principles Board (APB) (1970), "Basic concepts and accounting principles underlying financial statements of business enterprises", Statement No. 4, American Institute of Certified Public Accountants, October.

Afify, H. A. E. (2009), "Determinants of audit report lag: Does implementing corporate governance have any impact? Empirical evidence from Egypt", Journal of Applied Accounting Research, Vol.10 No. 1, pp.56 - 86.

Akle, Y.H. (2011), " Financial Reporting Timeliness in Egypt: A study of the Legal Framework and Accounting Standards, Internal Auditing \& Risk Management, Vol. 21 No.1, pp. 1-11.

American Institute of Certified Public Accountants (AICPA) (1973), "Report of the study group on the objectives of financial statements", October, AICPA, NY (usually referred to as the Trueblood Report).

Aubert, F. (2009), "Determinants of corporate financial reporting lag: The French empirical evidence", Journal of Accounting and Taxation, Vol. 1 No.3, pp.053-060.

Badertscher, B. (2011), "Overvaluation and the choice of alternative earnings management mechanisms", The Accounting Review, Vol. 86 No.5, pp.1491-1518

Bagnoli, M., W. Kross, and S. Watts (2002), 'The Information in Management's Expected Earnings Report date: A Day Late, A Penny Short', Journal of Accounting Research, Vol. 40 No.5, pp. 1275-1296.

Bamber, E. M., Bamber, L.S, and Schoderbek, M. P. (1993), "Audit structure and other determinants of audit report lag: an empirical analysis", Auditing: A Journal of Practice and Theory, Vol.12 No.1, pp.1-23.

Barton, J. (2001), "Does the use of financial derivatives affect earnings management decisions? ", The Accounting Review, Vol.76 No.1, pp.1-26. 
Bartov, E. and Mohanram, P. (2004), "Private Information, Earnings Manipulations, and Executive Stock-Option Exercises", The Accounting Review, Vol. 79 No. 4, pp. 889-920.

Begley, J., and P. Fischer (1998), 'Is There Information in an Earnings Announcement Delay?', Review of Accounting Studies, Vol. 3 No.4, pp. 347-363.

Braam, G., Nandy, M., Weitzel, U, and Lodh, S. (2015, "Accrualbased and real earnings management and political connections", The International Journal of Accounting, Vol. 50, pp.111-141.

Brown, N. C., Christensen, T.E. and Elliott, W. B. (2012), "The Opportunistic Timing of Quarterly "Pro Forma" Earnings Announcements", Journal of Business Finance \& Accounting, Vol.39 No.3-4, pp. 315-359.

Carslaw, C.A. and Kaplan, S.E. (1991), "An examination of audit delay: further evidence from New Zealand", Accounting and Business Research, Vol. 22 No. 85, pp. 21-32.

Chai, M. L. and Tung, S. (2002), "The Effect of Earnings Announcement Timing on Earnings Management", Journal of Business Finance \& Accounting, Vol. 29 No.9-10, pp.1137-1354.

Chambers, A.E. and Penman, S.H. (1984), "Timeliness of reporting and the stock price reaction to earnings announcements", Journal of Accounting Research, Vol. 22 No. 1, pp.21-47.

Che-Ahmad, A., and Abidin, S. (2001), "Auditor Industry Specialisation, Brand Name Auditors and Financial Reporting Lag”, Working Paper, University Utara Malaysia, pp. 1 - 8.

Chen, J. Z., Rees, L., and Sivaramakrishnan, K. (2010), “ On the Use of Accounting vs. Real Earnings Management to Meet Earnings Expectations - A Market Analysis", Working Paper, available at: http://ssrn.com/abstract=1070122. (Accessed April 2015).

Chung, Y., Pan, L., Huang, S.Y., and Chen, K.C. (2015), "Do firms change earnings management behavior after receiving financial forecast warnings?", Global Finance Journal, Article in press, pp.1-17.

Cohen, D. A., Dey, A., Lys, T. and Sunder, S. (2007), 'Earnings Announcement Premia and the Limits to Arbitrage', Journal of Accounting and Economics, Vol. 43 No.2-3, pp. 153-180. 
Cohen, D., and Zarowin, P. (2008)," Economic Consequences of Real and Accrual-Based Earnings Management Activities", Working Paper, Leonard N. Stern School of Business, New York University. Cohen, D., and Zarowin, P. (2010), "Accrual-based and real earnings management activities around seasoned equity offerings", Journal of Accounting and Economics, Vol. 50 No.1, pp. 2-19.

Cupertino, C.M., Martinez, A.L., and Da Costa, N.C.A., (2015), "Earnings manipulations by real activities management and investors' perceptions", Research in International Business and Finance, Vol.34, pp.309-323.

Coulton, J., Taylor, S. and Taylor, S. (2005), "Is 'benchmark beating' by Australian firms evidence of earnings management?", Accounting and Finance, Vol.45, pp. 553-576.

Courtis, J. K. (1976), "Relationships between timeliness in corporate reporting and corporate attributes", Accounting and Business Research, Vol.6, pp.46-56.

Davies, B. and Whittred, G.P. (1980), "The association between selected corporate attributes and timeliness in corporate reporting: further analysis"', ABACUS, Vol. 16 No. 1, pp. 48-60.

Dechow, P. M., and Skinner, D. J. (2000), "Earnings management: Reconciling the views of accounting academics, practitioners, and regulators", Accounting Horizons, Vol.14 No.2, pp. 235-250.

Degeorge, F., Patel, J. and Zeckhauser, R. (1999), "Earnings Management to Exceed Thresholds", The Journal of Business, Vol. 72 No. 1, pp.1-33.

Doukakis, L.C., (2014), "The effect of mandatory IFRS adoption on real and accrual-based earnings management activities", Journal of Accounting and Public policy, Vol. 33, pp.551-572.

Enofe, A. O., Osarumwense O. E. and Ejiemen, C. O. (2013), "Audit Delay and Audit Quality: The Nigerian experience", Research Journal of Social Science \& Management, Vol. 3 No. 4, pp. 7583.

Enomoto, M., Kimura, F. and Yamaguchi, T. (2013), “Accrual-Based and Real Earnings Management: An International Comparison for Investor Protection", Working Paper, Research Institute For Economics and Business Administration, Kobe University.

Ezat, A. and El-Masry, A. (2008), "The impact of corporate governance on the timeliness of corporate internet reporting by 
Egyptian listed companies", Managerial Finance, Vol. 34 No.12, pp. 848-867.

Field, A. (2009), Discovering Statistics Using SPSS, Third Edition, SAGA Publication, London, UK.

Fields, T., Lyz, T. and Vincent, L. (2001), "Empirical research on accounting choice", Journal of Accounting and Economics, Vol.31 No.1-3, pp.255-308.

Frost, C.A. and Pownall, G. (1994), "Accounting Disclosure Practices in the United States and the United Kingdom", Journal of Accounting Research, Vol. 32 No. 1, pp.75-102.

Gaver, J., and Paterson, J. (1999), "Managing insurance company financial statements to meet regulatory and tax reporting goals", Contemporary Accounting Research, Vol. 16 No.2, pp. 207-241.

Ge, W. and Kim, J.B., (2014), "Real earnings management and the cost of new corporate bonds", Journal of Business Research, Vol. 67, pp.641-647.

Givoly, D. and Palmon, D. (1982), "Timeliness of annual earnings announcements: some empirical evidence", The Accounting Review, Vol. 57 No. 3, pp. 485-508.

Graham, J.R., Harvey, C.R., and Rajgopal, S. (2005), "The economic implications of corporate financial reporting", Journal of Accounting and Economics, Vol.40 No.1-3, pp.3-37.

Gunny, K.A. (2010), "The Relation Between Earnings Management Using Real Activities Manipulation an Future Performance: Evidence from Meeting Earning Benchmarks. Contemporary Accounting Research, Vol. 27 No. 3, pp. 855-888.

Han, C. and S. Wang (1998), 'Political Costs and Earnings Management of Oil Companies during the 1990 Persian Gulf Crises', The Accounting Review, Vol. 73, pp. 103-117.

Han, J. C. Y., and Wild, J. J. (1997), "Timeliness of reporting and earnings information transfers", Journal of Business Finance and Accounting, Vol.24, pp.527-540.

Hashim, F., Hashim, F. and Jambari, A. (2013), " Relationship between Corporate Attributes and Timeliness in Corporate Reporting: Malaysian Evidence", Journal Teknologi (Social Sciences), Vol.64 No.2, pp. 115-119. 
Haw, I., Qi, D. and Wu, W. (2000), "Timeliness of annual report releases and market reaction to earnings announcements in an emerging capital market: The case of China", Journal of International Financial Management and Accounting, Vol. 11 No. 2, pp.108-131.

Healy, P. M. and Wahlen, J. M. (1999), "A Review of the Earnings Management Literature and its Implications for Standard Setting", Accounting Horizons, Vol. 13 No.4, pp.365-383.

Hossain, M.A. and Taylor, P.J. (1998), "An examination of audit delay: evidence from Pakistan", Working Paper, available at: http://www.mahossain.com/images/papers/Publications_in_the_Ref ereed_Conference_Proceedings/34.\%20Relationship\%20between\% 20Selected\%20Corporate\%20Attributes.pdf. (accessed April 2015).

International Accounting Standard Board (IASB) (2015), "Exposure Draft Conceptual Framework for Financial Reporting", IFRS Foundation Publications Department, London, United Kingdom.

Jaggi, B. and Tsui, J. (1999), "Determinants of audit report lag: further evidence from Hong Kong", Accounting and Business Research, Vol. 30 No. 1, pp. 17-28.

Kinney Jr., W. R., and McDaniel, L. S. (1993), "Audit delay for firms correcting quarterly earnings", Auditing: A Journal of Practice and Theory, Vol.12, pp.135-142.

Kothari, S.P., Mizik, M. and Roychowdhury, S. (2012), "Managing for the Moment: The Role of Real Activity versus Accruals Earnings Management in SEO Valuation", The accounting Review, In Press.

Krishnan, J. and Yang, J. (2009), "Recent Trends in Audit Report and Earnings Announcement Lags", Accounting Horizons, Vol. 23 No.3, pp.265-288.

Kross, W. and Schroeder, D. (1984), "An empirical investigation of the effect of quarterly earnings announcement timing on stock returns", Journal of Accounting Research, Vol. 22 No.1, pp.153176.

Kuo, J., Ning, L., and Song, X., (2014), "The Real and Accrual-based Earnings Management Behaviors: Evidence from the Split Share Structure Reform in China", The International Journal of Accounting, Vol. 49, pp.101-136. 
Lee, H. Y. and Son, M. (2009), "Earnings announcement timing and earnings management", Applied Financial Economics, Vol. 19 No. 1, pp. 319-326.

Lee, Y.C. and Lu, C.C. (2015), "Is Earnings Information Superior to Net Income as a Measure of Future Earnings? A Study on Accruals and Real Earnings Management", International Journal of Financial Research, Vol.6 No.1, pp. 119-136.

Lin, Y. and Shen, C., (2015), "Family firms' credit rating, idiosyncratic risk, and earnings management", Journal of Business Research, Vol.68, pp.872-877.

Modugu, P., Eragbhe, E. and Ikhatua, O. (2012), "Determinants of Audit Delay in Nigerian Companies: Empirical Evidence", Research Journal of Finance and Accounting, Vol. 3 No. 6, pp. 46-54.

Moradi, M., Salehi, M. and Ayask, S., (2013), " The Relationship between Delay in Announcing Quarterly Forecasts of Annual Earnings and the Type of Earnings News", Organizacija, Vol. 46 No. 2, pp. 64-71.

Owusu-Ansah, S. (2000), "Timeliness of corporate financial reporting in emerging capital markets: empirical evidence from the Zimbabwe Stock Exchange", Accounting and

Business Research, Vol. 30 No. 3, pp. 241-54.

Owusu-Ansah, S. and Leventis, S. (2006), "Timeliness of corporate annual financial reporting in Greece", European Accounting Review, Vol. 15 No. 2, pp. 273-87.

Pincus, M. and Rajgopal, S. (2002), "The interaction between accrual management and hedging: Evidence from oil and gas firms", The Accounting Review, Vol.77 No.1, pp.127-160.

Rahmawati, E., Sofocleous, S. and Wickremasinghe, G. (2013), "Information Content and Determinants of Timeliness of Financial Reporting in Indonesia", Working Paper, available at: http://baa.group.shef.ac.uk/download papers/index.php?submit= download. (accessed April 2015).

Reza, S. and Poudeh, T. (2014), "Audit Report Delay and Short-Term Debt Maturity", Journal of Social Issues \& Humanities, Vol. 2 No. 2, pp. 32-36. 
Robb, S. W. G. (1998), "The Effect of Analysts' Forecasts on Earnings Management in Financial Institutions", Journal of Financial Research, Vol. 21, No. 3, pp. 315-331.

Roychowdhury, S. (2006), "Earnings management through real activities manipulation", Journal of Accounting and Economics, Vol. 42 No.3, pp.335-370.

Roychowdhury, S. and Sletten, E. (2012), "Voluntary Disclosure Incentives and Earnings Informativeness", The Accounting Review, Vol. 87 No.5, pp.1679-1708.

Schipper, K. (1989), "Commentary on earnings management", Accounting Horizon, Vol.3 No.4, pp. 91-102.

Soltani, B. (2002), "Timeliness of corporate and audit reports: some empirical evidence in the French context", International Journal of Accounting, Vol. 37, pp. 215-46.

Skinner, D. (1994), "Why firms voluntarily disclose bad news", Journal of Accounting Research, Vol. 32 No.1, pp.38-60.

Trueman, B. (1990), "Theories of Earnings--Announcement Timing", Journal of Accounting and Economics, Vol.13 No.3, pp.285-301.

Turel, A. (2010), "Timeliness of financial reporting in emerging capital markets: Evidence from Turkey", Stanbul University Isletme Fakultesi Dergisi, Vol. 39 No. 2, pp. 227-240.

Zang, A.Y. (2012), "Evidence on the Trade-Off between Real Activities Manipulation and Accrual-Based Earnings Management", The Accounting Review, Vol. 87 No.2, pp. 675703. 